\title{
Erratum to: Carbon-based layers for mechanical machining of wood-based materials
}

\author{
W. Kaczorowski • D. Batory • W. Szymański • \\ P. Niedzielski
}

Published online: 18 March 2012

(C) Springer-Verlag 2012

\section{Erratum to: Wood Sci Technol \\ DOI 10.1007/s00226-012-0469-8}

Unfortunately, the third author's last name was misspelt in the original publication of the article. The correct spelling should be "W. Szymański".

The online version of the original article can be found under doi:10.1007/s00226-012-0469-8.

W. Kaczorowski $(\bowtie) \cdot$ D. Batory $\cdot$ P. Niedzielski

Institute of Materials Science and Engineering, Technical University of Lodz,

Stefanowskiego St. 1/15, 90-924 Lodz, Poland

e-mail: witold.kaczorowski@gmail.com

W. Szymański

Faculty of Wood Technology, Poznań University of Life Sciences,

Wojska Polskiego St. 28, 60-637 Poznań, Poland 